\title{
Chronic intermittent hypoxia increases encoding pigment epithelium-derived factor gene expression, although not that of the protein itself, in the temporal cortex of rats ${ }^{* * * * *}$
}

\author{
Hipóxia intermitente crônica aumenta a expressão gênica, mas não \\ proteica, de pigment epithelium-derived factor, no córtex temporal de ratos
}

\author{
Guilherme Silva Julian, Renato Watanabe de Oliveira, Vanessa Manchim Favaro, \\ Maria Gabriela Menezes de Oliveira, Juliana Cini Perry, Sergio Tufik, Jair Ribeiro Chagas
}

\begin{abstract}
Objective: Obstructive sleep apnea syndrome is mainly characterized by intermittent hypoxia (1H) during sleep, being associated with several complications. Exposure to $\mathrm{lH}$ is the most widely used animal model of sleep apnea, short-term $\mathrm{lH}$ exposure resulting in cognitive and neuronal impairment. Pigment epithelium-derived factor (PEDF) is a hypoxiasensitive factor acting as a neurotrophic, neuroprotective, and antiangiogenic agent. Our study analyzed performance on learning and cognitive tasks, as well as PEDF gene expression and PEDF protein expression in specific brain structures, in rats exposed to long-term $1 \mathrm{H}$. Methods: Male Wistar rats were exposed to $\mathrm{lH}$ (oxygen concentrations of 21-5\%) for 6 weeks-the chronic $\mathrm{lH}(\mathrm{ClH})$ group-or normoxia for 6 weeks-the control group. After $\mathrm{ClH}$ exposure, a group of rats were allowed to recover under normoxic conditions for 2 weeks (the $\mathrm{ClH}+\mathrm{N}$ group). All rats underwent the Morris water maze test for learning and memory, PEDF gene expression and PEDF protein expression in the hippocampus, frontal cortex, and temporal cortex being subsequently assessed. Results: The $\mathrm{ClH}$ and $\mathrm{ClH}+\mathrm{N}$ groups showed increased $P E D F$ gene expression in the temporal cortex, PEDF protein expression remaining unaltered. PEDF gene expression and PEDF protein expression remained unaltered in the frontal cortex and hippocampus. Long-term exposure to $\mathrm{lH}$ did not affect cognitive function. Conclusions: Long-term exposure to $\mathrm{lH}$ selectively increases $P E D F$ gene expression at the transcriptional level, although only in the temporal cortex. This increase is probably a protective mechanism against $1 \mathrm{H}$-induced injury.
\end{abstract}

Keywords: Sleep apnea, central; Disease models, animal; Cognition; Sleep; Sleep apnea, obstructive.

\section{Resumo}

Objetivo: A síndrome da apneia obstrutiva do sono caracteriza-se principalmente por episódios de hipóxia intermitente (HI) durante o sono e associa-se a diversas complicações. A exposição à Hl é o mais usado modelo animal de apneia do sono, e protocolos de curta duração causam diversos prejuízos cognitivos e neuronais. Pigment epithelium-derived factor (PEDF, fator derivado do epitélio pigmentado) é um fator neurotrófico, neuroprotetor e antiangiogênico sensível à hipóxia celular. Nosso estudo analisou o desempenho em tarefas cognitivas e de aprendizagem, bem como a expressão do gene $P E D F$ e da proteína PEDF em estruturas cerebrais específicas em ratos expostos a $\mathrm{Hl}$ de longa duração. Métodos: Ratos Wistar foram expostos a HI (21-5\% de oxigênio) durante 6 semanas - o grupo Hl crônica (HIC) - ou a normóxia durante 6 semanas - o grupo controle. Após a exposição à HIC, um grupo de ratos foi exposto a normóxia durante 2 semanas (o grupo $\mathrm{HIC}+\mathrm{N}$ ). Todos os animais foram submetidos ao labirinto aquático de Morris para avaliação de memória e aprendizado; avaliou-se também a expressão do gene PEDFe da proteína PEDF no hipocampo e nos córtices frontal e temporal. Resultados: Os grupos $\mathrm{HIC}$ e $\mathrm{HIC}+\mathrm{N}$ apresentaram um aumento de expressão do gene $P E D F$ no córtex temporal, porém sem aumento dos níveis proteicos. A expressão do gene $P E D F$ e da proteína PEDF manteve-se inalterada nas demais estruturas. A exposição de longa duração à Hl não afetou a função cognitiva. Conclusões: A exposição de longa duração à $\mathrm{Hl}$ aumenta seletivamente a expressão do gene $P E D F$ ao nível transcricional, embora apenas no córtex temporal. Esse aumento é provavelmente um mecanismo de proteção contra a Hl.

Descritores: Apneia do sono tipo central; Modelos animais de doenças; Sono; Cognição; Apneia do sono tipo obstrutiva.

\footnotetext{
*Study carried out in the Department of Psychobiology, Federal University of São Paulo Paulista School of Medicine, São Paulo, and in the Department of Biosciences, Federal University of São Paulo, Baixada Santista Campus, Santos, Brazil. Correspondence to: Jair Ribeiro Chagas. Rua Napoleão de Barros, 925, $3^{\circ}$ andar, CEP 04024-002, São Paulo, SP, Brasil. Tel/Fax: 5511 2149-0144.E-mail: jchagas1@gmail.com

Financial support: This study received financial support from the Associação Fundo de Incentivo à Pesquisa (AFIP, Association for the Incentive Funding of Research), the Conselho Nacional de Desenvolvimento Científico e Tecnológico (CNPq, National Council for Scientific and Technological Development; Fellowship Grant nos. 558924/2008-5 to Juliana Cini Perry, 308652/2011-8 to Maria Gabriela Menezes de Oliveira, 301974/2011-0 to Sergio Tufik, and 310040/2011-6 to Jair Ribeiro Chagas), the Coordenação de Aperfeiçoamento de Pessoal de Nivel Superior (CAPES, Office for the Advancement of Higher Education), and the Fundação de Amparo à Pesquisa do Estado de São Paulo (FAPESP, São Paulo Research Foundation; Grant nos. 2011/15060-4 to Guilherme Silva Julian, 2011/16011-6 to Renato Watanabe de Oliveira, and 2011/03791-3 to Vanessa Manchim Favaro).

Submitted: 8 August 2014. Accepted, after review: 11 November 2014.

*A A versão completa, em português, deste artigo está disponível em: www.jornaldepneumologia.com.br
} 


\section{Introduction}

Obstructive sleep apnea (OSA) is the most common sleep-related breathing disorder and is a public health issue because of its high prevalence. ${ }^{(1,2)}$ It is characterized by recurrent episodes of partial or complete upper airway obstruction, leading to sleep fragmentation, hypercapnia, and nocturnal intermittent hypoxia (IH). A number of animal models of OSA have been developed over the years, ${ }^{(3)}$ most of which have focused on $\mathrm{IH}$. The $\mathrm{IH}$ model produces several effects that are similar to those of OSA, including cognitive impairment, changes in sleep architecture, insulin resistance, and hypertension. ${ }^{(4-10)}$ This suggests that $\mathrm{IH}$ plays an important role in OSA, ${ }^{(11)}$ affecting even cognition.

Learning and cognition require a process known as synaptic plasticity, which is the ability of synapses to strengthen or weaken their connections. ${ }^{(12)}$ Several factors control synaptic plasticity, including neurotransmitters and neurotrophic factors that play an essential role in the growth and survival of developing neurons. One such factor is pigment epitheliumderived factor (PEDF), which has antiangiogenic, neuroprotective, and neurotrophic activity.

As a neuroprotective agent, PEDF reduces glutamate-mediated excitotoxicity ${ }^{(13-15)}$ and attenuates ischemic brain damage. ${ }^{(16)}$ As a neurotrophic agent, PEDF induces the expression of other factors, such as brainderived neurotrophic factor, glial cell line-derived neurotrophic factor, and nerve growth factor, ${ }^{(17)}$ and increases the formation of dendritic spines. ${ }^{(18)}$ The sensitivity of PEDF to hypoxic exposure has been shown to vary, ${ }^{(19,20)}$ with divergent results regarding the relationship between PEDF and oxygen levels.

Although the effects of short-term $\mathrm{lH}$ on learning, cognition, memory, and neurotrophic factors are known, ${ }^{(21)}$ the effects of longterm $\mathrm{lH}$ remain unclear. Therefore, in order to determine the relationships among PEDF, chronic intermittent hypoxia $(\mathrm{ClH})$, and memory, as well as to improve the understanding of the role of PEDF in $\mathrm{CIH}$, the present study examined spatial memory, $P E D F$ gene expression, and PEDF protein expression in a rat model of $\mathrm{ClH}$. Indeed, the effects of in vivo hypoxia models on PEDF messenger RNA (mRNA) and protein levels remain unknown.

\section{Methods}

In the present study, we used 45 adult male Wistar Hannover rats provided by the Federal University of São Paulo Centro de Desenvolvimento de Modelos Experimentais para Medicina e Biologia (CEDEME, Center for the Development of Biological and Biomedical Models), located in the city of São Paulo, Brazil. The study was approved by the Animal Research Ethics Committee of the Federal University of São Paulo, located in the city of São Paulo, Brazil (Protocol n² 2025/11).

All animals were housed at $22^{\circ} \mathrm{C}$ on a $12 / 12-\mathrm{h}$ light/dark cycle (lights on at 7:00 a.m. and off at 7:00 p.m.) and were given ad libitum access to food and water. The rats were randomly assigned to the control group ( $\mathrm{n}=15)$; the $\mathrm{ClH}$ group ( $n=15$ ), which comprised animals exposed to $\mathrm{lH}$ for 6 weeks $^{(22)}$; or the $\mathrm{ClH}+\mathrm{N}$ group, which comprised animals exposed to 6 weeks of $\mathrm{lH}$ followed by 2 weeks of recovery in normoxia. ${ }^{(22)}$

The Morris water maze (MWM) test was performed in a separate room in a black circular pool (of $200 \mathrm{~cm}$ in diameter by $40 \mathrm{~cm}$ in height) filled with water at approximately $23^{\circ} \mathrm{C}$ to a depth of $25 \mathrm{~cm}$. For animal orientation, distinct visual cues were placed on each wall of the room. A black platform of $10 \mathrm{~cm}$ in diameter was placed $2 \mathrm{~cm}$ below the surface and fixed in the center of the target quadrant.

Two separate tests were performed. The first involved 8 control rats and the 15 rats in the $\mathrm{ClH}$ group, and the second involved 7 control rats and the 15 rats in the $\mathrm{ClH}+\mathrm{N}$ group. Spatial learning sessions were conducted on five consecutive days, in the last week of exposure to $\mathrm{ClH}$ or $\mathrm{ClH}+\mathrm{N}$. During the test week, the rats in the $\mathrm{ClH}$ group were exposed to $\mathrm{lH}$ for $8 \mathrm{~h} /$ day. The spatial learning sessions consisted of four 1-min trials for each animal, with a 1-min interval between trials. Rats began the MWM from different quadrants in the pool at the start of each trial.

After the last training day, all rats underwent a 1-min trial of free swimming in the MWM without the platform. The ratio between the time spent in the target quadrant and the time spent in other quadrants was used in order to determine spatial memory. The tests were performed one day after the last $\mathrm{ClH}$ exposure for the $\mathrm{ClH}$ group and after the 2 weeks of normoxia for the $\mathrm{ClH}+\mathrm{N}$ group. Each group had its own control group. All trials were analyzed by identifying contrast between 
the (white) animal and the (black) tank, with the Noldus EthoVision XT video tracking software, version 7.0 (Noldus Information Technology Inc., Leesburg, VA, USA).

Immediately after the MWM test, all rats were euthanized by rapid decapitation. The brains were rapidly removed and dissected to remove the hippocampus, frontal cortex, and temporal cortex. All tissues were rapidly dissected on dry ice and stored at $-80^{\circ} \mathrm{C}$ until RNA extraction. It has been reported that $\mathrm{ClH}$ affects spatial memory and learning, ${ }^{(6,9,23)}$ which is why we studied PEDF expression in the hippocampus, frontal cortex, and temporal cortex (areas related to spatial and visual learning).

For all structures, total RNA extraction was performed with TRIzol ${ }^{\oplus}$ (Thermo Fisher Scientific Inc., Waltham, MA, USA), in accordance with the manufacturer instructions. After extraction, RNA was treated with DNAse 1 (Thermo Fisher Scientific Inc.), its quality and integrity being evaluated by visualization of rRNA after agarose gel electrophoresis. Quantitation was performed by means of spectrophotometry at $260 \mathrm{~nm}$ (NanoDrop, Wilmington, DE, USA), and purity was estimated by a 260/280-nm ratio $>1.8$. One $\mu \mathrm{g}$ of RNA from each dissected structure was reverse transcribed with the High Capacity cDNA Reverse Transcription Kit (Applied Biosystems, Foster City, CA, USA), in accordance with the manufacturer instructions.

Each cDNA was used as a template for realtime PCR amplification with fluorescent-labeled probes (TaqMan ${ }^{\oplus}$; Applied Biosystems) and the 7500 Real-Time PCR System (Applied Biosystems) for detection. The level of expression of the PEDF gene (Rn00709999_m1) was determined by using beta-actin (Rn00667869_m1) and glyceraldehyde3-phosphate dehydrogenase (Rn01775763_g1) as housekeeping genes. ${ }^{(22)}$ Each reaction was performed in a final volume of $20 \mu \mathrm{L}$, i.e., $1 \mu \mathrm{L}$ of cDNA diluted in water and $19 \mu \mathrm{L}$ of master mix $(1 \mu \mathrm{L}$ of TaqMan assay probe, $10 \mu \mathrm{L}$ of TaqMan $^{\otimes}$ Universal PCR Master Mix, and $8 \mu \mathrm{L}$ of water), threshold cycle values being maintained between 15.0 and 33.0. All samples were run in triplicate, and average values were calculated.

For Western blotting analyses, all tissues were homogenized in lysis buffer ( $50 \mathrm{mM}$ Tris- $\mathrm{HCl}$, pH 7.4; $100 \mathrm{mM} \mathrm{NaCl}$; 0.1\% Triton X-100 [The Dow Chemical Company, Midland, MI, USA]; $1 \mathrm{mM}$ EDTA; and a protease inhibitor cocktail
[Sigma-Aldrich, St. Louis, MO, USA]), $10 \mu \mathrm{L}$ of lysis buffer being used for each $1 \mathrm{mg}$ of tissue. After homogenization, the lysate was cleared by centrifugation at $13,000 \mathrm{rpm}$ for $10 \mathrm{~min}$ at $4^{\circ} \mathrm{C}$, the supernatant was collected, and supernatant proteins were quantified by the Lowry method (Bio-Rad Laboratories, Inc., Hercules, CA, USA).

One hundred micrograms of protein extract from all brain structures were incubated at $95^{\circ} \mathrm{C}$ for $10 \mathrm{~min}$ with sample buffer, subjected to SDS-PAGE (10\%), and transferred to a 0.2- $\mu \mathrm{m}$ nitrocellulose membrane (Hybond ECL; GE Healthcare, Chalfont St Giles, UK). After protein transfer, the membrane was blocked in a solution of 5\% skim milk in TBS with Tween 20 for $2 \mathrm{~h}$ at room temperature and incubated overnight at $4^{\circ} \mathrm{C}$ with PEDF primary antibody (BioProducts MD, LLC, Middletown, MD, USA) and glyceraldehyde3-phosphate dehydrogenase primary antibody (Sigma-Aldrich) at 1:500 and 1:1,000,000 dilutions, respectively. The membrane was developed with goat anti-rabbit secondary antibody, labeled with Alexa Fluor 680 fluorescent dye (Thermo Fisher Scientific Inc.), incubated for $1 \mathrm{~h}$ in blocking buffer at 1:10,000 dilution, washed with TBS with Tween 20, and scanned on an Odyssey Infrared Imaging System (LI-COR Biosciences, Lincoln, NE, USA). The images were analyzed with the Odyssey Application Software, version 1.2 (Ll-COR Biosciences).

All data were initially analyzed for normality of distribution and homogeneity of variance with the Kolmogorov-Smirnov test and Levene's test, respectively. When data were not normally distributed or heterogeneity of variance was identified, a Z score correction was performed, and the groups were compared by one-way ANOVA followed by Dunnett's post hoc test, when necessary. With regard to the Western blotting results, the groups were compared by the Kruskal-Wallis test because of the small number of animals per group. With regard to the MWM test results, the groups were compared by repeated measures ANOVA, followed by Tukey's post hoc test. All data were expressed as mean \pm standard error of the mean. The level of significance was set at $p \leq 0.05$.

\section{Results}

All rats learned the MWM, the difference between their performance during the training phase and their performance during the acquisition 
phase being significantly different. A continuous decrease in latency time shows the learning process $\left(F_{1,17}=32.561, p<0.001\right.$ for the control group vs. the $\mathrm{ClH}$ group during the training phase; $\mathrm{F}_{1,23}$ $=38.916, p<0.001$ for the control group vs. the $\mathrm{ClH}+\mathrm{N}$ group during the training phase). As can be seen in Figures 1 and 2, neither $\mathrm{ClH}$ nor $\mathrm{ClH}+\mathrm{N}$ had any effect on the learning process $\left(\mathrm{F}_{1,17}=1.393, \mathrm{p}=0.246\right.$ for the $\mathrm{ClH}$ group during

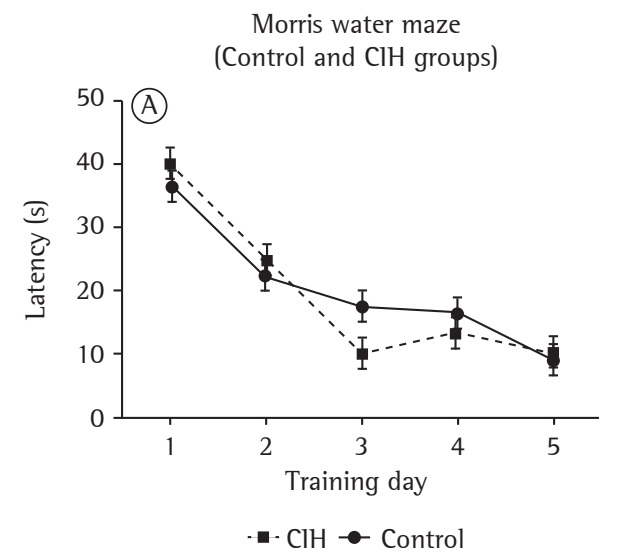

the acquisition phase vs. the $\mathrm{ClH}$ group during the training phase; $F_{1,23}=1.837, p=0.128$ for the $\mathrm{ClH}+\mathrm{N}$ group during the acquisition phase vs. the $\mathrm{ClH}+\mathrm{N}$ group during the training phase), with no evidence of learning impairment in either group when compared with the control group.

Memory retention can be evaluated by removing the platform (probe trials). A probe trial shows whether animals learned the task and whether

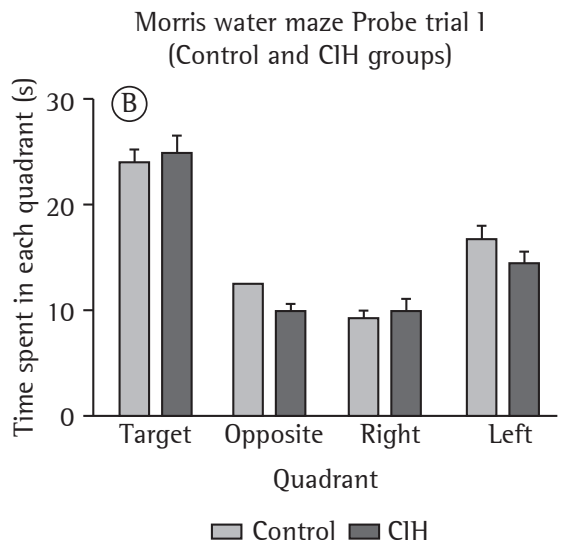

Figure 1 - Effects of chronic intermittent hypoxia $(\mathrm{ClH})$ on spatial learning and memory. In A, comparison between Wistar rats exposed to $\mathrm{ClH}$ (the $\mathrm{ClH}$ group) and control rats (the control group) in terms of their performance during Morris water maze (MWM) testing. For 5 consecutive days, rats underwent four 1-min trials, with a 1-min interval between trials. No statistically significant differences were observed. All data are presented as mean \pm SD. Two-way repeated measures ANOVA followed by Tukey's post hoc test. In $\mathrm{B}$, comparison between the control and $\mathrm{ClH}$ groups in terms of the time spent in each MWM quadrant, in order to evaluate spatial memory on day 6 . No statistically significant differences were observed. All data are expressed as mean \pm standard error of the mean.

Morris water maze (Control and $\mathrm{ClH}+\mathrm{N}$ groups)

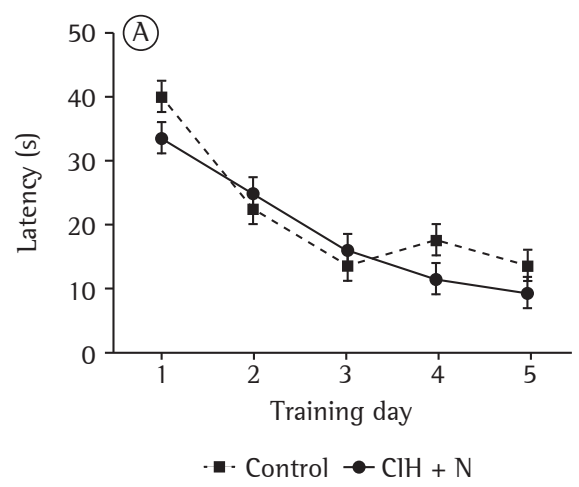

Morris water maze Probe trial 11 (Control and $\mathrm{ClH}+\mathrm{N}$ groups)

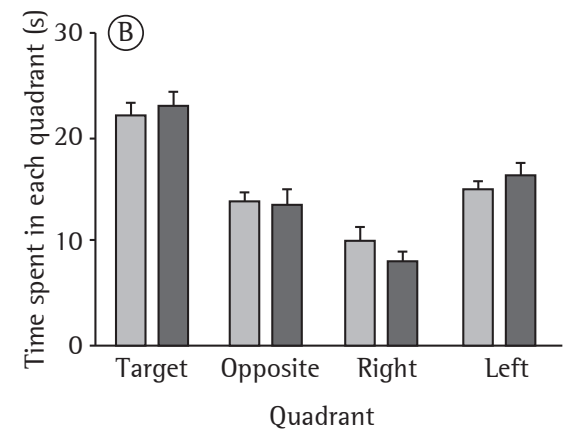

$\square$ Control $\square \mathrm{ClH}+\mathrm{N}$

Figure 2 - Effects of exposure to chronic intermittent hypoxia $(\mathrm{ClH})$ followed by 2 weeks of normoxia on spatial learning and memory. In A, comparison between Wistar rats exposed to $\mathrm{ClH}$ plus two weeks of normoxia (the $\mathrm{ClH}+\mathrm{N}$ group) and control rats (the control group) in terms of their performance during Morris water maze (MWM) testing. For 5 consecutive days, rats underwent four 1-min trials, with a 1-min interval between trials. No statistically significant differences were observed. All data are presented as mean \pm SD. Two-way repeated measures ANOVA followed by Tukey's post hoc test. In B, comparison between the control and $\mathrm{ClH}+\mathrm{N}$ groups in terms of the time spent in each MWM quadrant, in order to evaluate spatial memory on day 6. No statistically significant differences were observed. All data are expressed as mean \pm standard error of the mean. 
Table 1 - Comparison of different chronic intermittent hypoxia protocols in terms of cognitive effects, evaluation method, minimum oxygen concentration, cycle duration, and exposure duration.

\begin{tabular}{|c|c|c|c|c|c|c|}
\hline Author & $\begin{array}{c}\text { Year of } \\
\text { publication }\end{array}$ & Cognitive effects & $\begin{array}{l}\text { Evaluation } \\
\text { method }\end{array}$ & $\begin{array}{c}\text { Minimum oxygen } \\
\text { concentration }\end{array}$ & $\begin{array}{c}\text { Cycle } \\
\text { duration }\end{array}$ & $\begin{array}{l}\text { Exposure } \\
\text { duration }\end{array}$ \\
\hline $\begin{array}{l}\text { Gozal } \\
\text { et al. }{ }^{(9)}\end{array}$ & 2001 & $\begin{array}{l}\text { Impaired learning and } \\
\text { spatial memory }\end{array}$ & MWM task & $10 \%$ & $1.5 \mathrm{~min}$ & 14 days \\
\hline $\begin{array}{l}\text { Row } \\
\text { et al. } .^{(25)}\end{array}$ & 2002 & $\begin{array}{l}\text { Impaired learning and } \\
\text { spatial memory }\end{array}$ & MWM task & $10 \%$ & $1.5 \mathrm{~min}$ & 14 days \\
\hline $\begin{array}{l}\text { Goldbart } \\
\text { et al. }{ }^{(6)}\end{array}$ & 2003 & $\begin{array}{l}\text { Impaired learning and } \\
\text { spatial memory; impaired } \\
\text { CREB phosphorylation }\end{array}$ & $\begin{array}{l}\text { MWM task } \\
\text { and CREB } \\
\text { phosphorylation }\end{array}$ & $10 \%$ & $1.5 \mathrm{~min}$ & $1-30$ days \\
\hline $\begin{array}{l}\text { Row } \\
\text { et al. }{ }^{(23)}\end{array}$ & 2007 & $\begin{array}{l}\text { Impaired working } \\
\text { memory }\end{array}$ & $\begin{array}{l}\text { Modified MWM } \\
\text { task }\end{array}$ & $10 \%$ & $1.5 \mathrm{~min}$ & 1-14 days \\
\hline $\begin{array}{l}\text { Perry } \\
\text { et al. }{ }^{(28)}\end{array}$ & 2008 & $\begin{array}{l}\text { Unaltered amygdala- } \\
\text { dependent memory }\end{array}$ & $\begin{array}{l}\text { Inhibitory } \\
\text { avoidance task }\end{array}$ & $10 \%$ & $2 \min$ & 3-21 days \\
\hline $\begin{array}{l}\text { Wall } \\
\text { et al. }{ }^{(26)}\end{array}$ & 2013 & Reduced LTP & $\begin{array}{l}\text { In vitro } \\
\text { measurement } \\
\text { of LTP }\end{array}$ & $5 \%$ & $1.5 \mathrm{~min}$ & 8 days \\
\hline $\begin{array}{l}\text { Shiota } \\
\text { et al. }{ }^{(27)}\end{array}$ & 2013 & $\begin{array}{l}\text { Unaltered learning and } \\
\text { spatial-memory }\end{array}$ & MWM task & $5 \%$ & $10 \min$ & 8 weeks \\
\hline $\begin{array}{l}\text { Julian } \\
\text { et al. }{ }^{(22)}\end{array}$ & - & $\begin{array}{l}\text { Unaltered learning and } \\
\text { spatial memory }\end{array}$ & MWM task & $5 \%$ & $3 \min$ & $\begin{array}{l}6 \text { weeks and } \\
6 \text { weeks }+2 \\
\text { weeks recovery }\end{array}$ \\
\hline
\end{tabular}

MWM: Morris water maze; LTP: long-term potentiation; and CREB: cAMP response element binding protein.

they were able to retain learned information. On probe trials 1 and 11 , no significant differences were observed between the $\mathrm{ClH}$ and control groups or between the $\mathrm{ClH}+\mathrm{N}$ and control groups in terms of the time spent in the target quadrant $\left(\mathrm{F}_{1,20}=0.122 ; \mathrm{p}=0.731\right.$ and $\mathrm{F}_{1,23}=0.278 ; \mathrm{p}=$ 0.603 , respectively; Figures 1 and 2), showing that neither $\mathrm{ClH}$ nor $\mathrm{ClH}+\mathrm{N}$ affected learning and memory retention processes.

Exposure to $\mathrm{ClH}$ did not affect PEDF gene expression in the hippocampus and frontal cortex $\left(\mathrm{F}_{2,21}=1.408 ; \mathrm{p}=0.267\right.$ and $\mathrm{F}_{2,21}=2.689 ; \mathrm{p}=$ 0.091 , respectively), mRNA levels having remained unaltered after 6 weeks of $1 \mathrm{H}$. In addition, PEDF gene expression remained unaltered after 6 weeks of $1 \mathrm{H}$ followed by 2 weeks of recovery in normoxia, showing that although hypoxia induces angiogenesis, $\mathrm{ClH}$ and $\mathrm{ClH}+\mathrm{N}$ did not affect the expression of $P E D F$, which is an important neurotrophic and antiangiogenic factor.

The relative mRNA expression of PEDF in the temporal cortex increased 1.5-fold after 6 weeks of exposure to $\mathrm{IH}\left(\mathrm{F}_{2,20}=6.583 ; \mathrm{p}=\right.$ 0.006 ; Dunnett's post hoc test: $p=0,004)$. After 2 weeks of recovery in normoxia, PEDF mRNA did not return to normal, being 1.3-fold higher in the $\mathrm{ClH}+\mathrm{N}$ group than in the control group (Dunnet's post hoc test; $p=0.029$; Figure 3 ). This suggests that it takes a long time for the effects of $\mathrm{ClH}$ to subside, or even that they are irreversible.

There were no significant changes in PEDF protein levels in the hippocampus $(\mathrm{H}(2)=1.192 ; \mathrm{p}$ $=0.551)$, frontal cortex $(H(2)=0.38 ; p=0.981)$, or temporal cortex $(\mathrm{H}(2)=2.577 ; \mathrm{p}=0.276)$ of animals exposed to $\mathrm{ClH}$ or $\mathrm{ClH}+\mathrm{N}$. Although $P E D F$ gene expression in the temporal cortex increased 1.5-fold, the protein levels remained unaltered (Figure 4). This might be due to the fact that Western blotting is less sensitive than real-time PCR, which is a much more accurate method.

\section{Discussion}

Short-term $1 \mathrm{H}$ models have several neurological implications: increased hippocampal and cortical apoptosis ${ }^{(9)}$; inhibition of cAMP response element binding protein phosphorylation; and learning and memory impairment. ${ }^{(6)}$ Our results show that exposure to $\mathrm{ClH}$ and $\mathrm{ClH}+\mathrm{N}$ did not affect learning and retention in a spatial memory task, being inconsistent with those of studies involving short-term exposure to $1 \mathrm{H} .{ }^{(6,9,23-26)}$ This might be due to differences in the hypoxia protocol (including differences in cycle and exposure duration) and in oxygen concentration. Studies involving short-term ( $\leq 30$-day) exposure to $\mathrm{lH}$ 


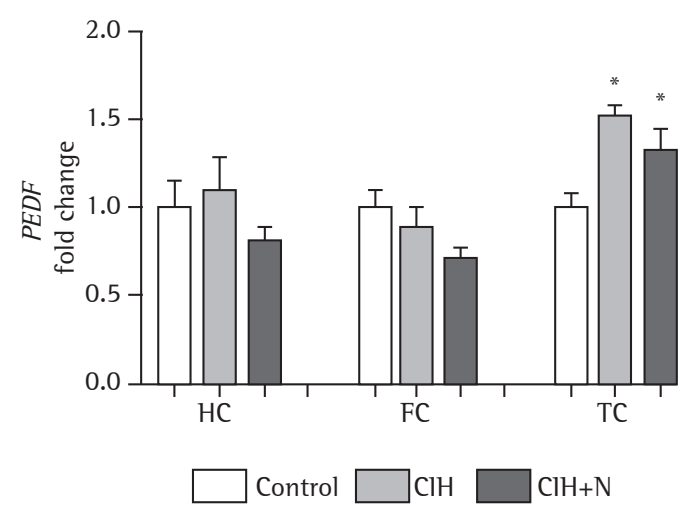

Figure 3 - Relative pigment epithelium-derived factor $(P E D F)$ gene expression in the central nervous system, glyceraldehyde-3-phosphate dehydrogenase and betaactin being used as housekeeping genes. PEDF gene expression was found to be increased, although only in the temporal cortex, in the chronic intermittent hypoxia $(\mathrm{ClH})$ and $\mathrm{ClH}$ plus 2 weeks of normoxia $(\mathrm{ClH}+\mathrm{N})$ groups when compared with the control group. ${ }^{*} p<0.05$ in comparison with the control group; one-way ANOVA followed by Dunnett's post hoc test. All data are expressed as mean \pm standard error of the mean. HC: hippocampus; FC: frontal cortex; and TC: temporal cortex.

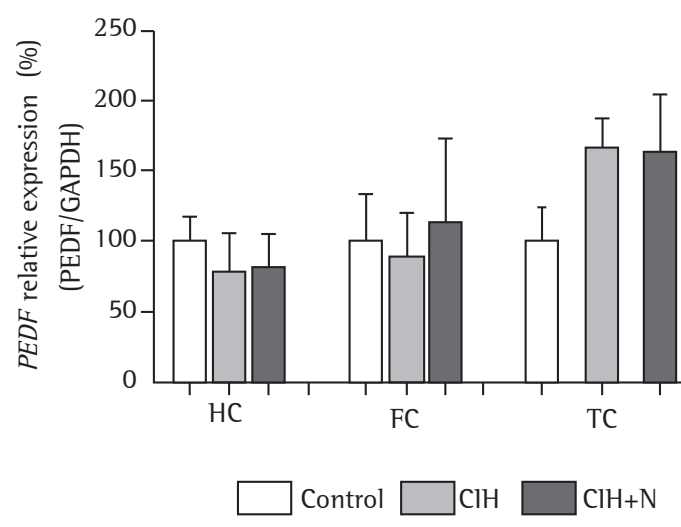

Figure 4 - Relative pigment epithelium-derived factor (PEDF) protein expression in the central nervous system, glyceraldehyde-3-phosphate dehydrogenase (GAPDH) being used as loading control. There were no significant differences in PEDF levels among the brain structures studied ( $p<0.05$ ). There were no significant differences in PEDF levels among the control, chronic intermittent hypoxia $(\mathrm{ClH})$, and $\mathrm{ClH}$ plus 2 weeks of normoxia $(\mathrm{ClH}+\mathrm{N})$ groups $(\mathrm{p}<0.05)$. One-way ANOVA. All data are expressed as mean \pm standard error of the mean. HC: hippocampus; FC: frontal cortex; and TC: temporal cortex.

and oxygen concentrations ranging from 21\% to 10\% have shown evidence of memory impairment (Table 1). A comparison of the findings of the studies described in Table 1 shows that cognitive response varies according to the $\mathrm{lH}$ protocol.

Studies have shown that memory retention processes are not affected by $\mathrm{ClH}$. Shiota et al. ${ }^{(27)}$ demonstrated that exposure to $\mathrm{lH}$ for 8 weeks with varying oxygen concentrations (ranging from 21\% to $5 \%$ ) did not affect learning and retention in the MWM task. Golbart et al. ${ }^{(6)}$ evaluated spatial reference memory in rats and demonstrated that short-term exposure to $1 \mathrm{H}$ selectively affects memory and cAMP response element binding protein phosphorylation, whereas long-term $\mathrm{lH}$ exposure does not. Perry et al. ${ }^{(28)}$ reported that rats exposed to $1 \mathrm{H}$ for 3 weeks did not show impaired acquisition/retention in an inhibitory avoidance task, an amygdala-dependent memory task, or an activity chamber.

The fact that long-term exposure to $\mathrm{lH}$ does not result in memory impairment might be due to neural adaptation after short-term exposure to $\mathrm{lH}$; although short-term exposure to $\mathrm{lH}$ affects learning and memory, long-term exposure does not. Therefore, $\mathrm{lH}$ models might not be the best animal models to study the cognitive effects of OSA, because of a possible adaptation response in animals. (29)

Our study showed that neither $\mathrm{ClH}$ nor $\mathrm{ClH}+\mathrm{N}$ affected PEDF gene expression or PEDF protein expression in the hippocampus. These results corroborate our behavioral results, which suggest that the hippocampus was able to exert its spatial learning function normally. Because PEDF has important neurotrophic and neuroprotective functions, PEDF levels are expected to remain unaltered in cases of unaltered learning and memory.

Our study showed that PEDF gene expression in the temporal cortex increased 1.5-fold in the $\mathrm{ClH}$ group and 1.3-fold in the $\mathrm{ClH}+\mathrm{N}$ group. This increase in $P E D F$ gene expression is similar to that observed in exposure to severe sustained hypoxia (an oxygen concentration of $0.2 \%$ ) in vitro; increased $P E D F$ gene expression can be a cellular defense mechanism to ensure cell survival under severe hypoxic conditions. ${ }^{(30)}$ In addition, a period of 2 weeks of recovery in normoxia after exposure to $\mathrm{ClH}$ is not enough to normalize PEDF gene expression, showing that $\mathrm{ClH}$-induced changes can be long-lasting. (31) Although PEDF gene expression increased in the $\mathrm{ClH}$ and $\mathrm{ClH}+\mathrm{N}$ groups, PEDF protein levels did not change. Divergent gene and protein 
expression profiles following severe sustained hypoxia have been reported, protein levels having remained unaltered and genetic expression having increased 2.0-fold. ${ }^{(30)}$

The effects of $\mathrm{ClH}$ on PEDF gene expression were not reversed after 2 weeks of recovery in normoxia in the $\mathrm{ClH}+\mathrm{N}$ group. This underscores the fact that $\mathrm{ClH}$ has persistent effects on biochemical and oxidative parameters in the brainstem and forebrain, which are related to hypersomnolence. ${ }^{(31)}$

The unaltered protein levels in the present study might also be due to increased PEDF catabolism, given that matrix metalloproteinases 2 and 9 show increased activity in hypoxic conditions and are involved in PEDF degradation. Therefore, increased PEDF levels followed by increased activity of matrix metalloproteinases 2 and 9 might result in unaltered PEDF protein levels. ${ }^{(32)}$ Conversely, VEGF, which is a potent angiogenic factor, is expressed differently among brain regions, VEGF levels remaining unaltered in the temporal cortex and being increased in the frontal cortex after exposure to $\mathrm{lH}$. In addition, VEGF regulates PEDF expression, supporting the idea of a negative feedback loop in the protein. ${ }^{(33)}$

The present study has some limitations. One is that $\mathrm{ClH}$ models simulate only one of the four major characteristics of OSA. Another limitation is that our $\mathrm{ClH}$ protocol included a low number of $\mathrm{IH}$ events per hour (simulating mild OSA). In summary, long-term exposure to $1 \mathrm{H}$ selectively increased $P E D F$ gene expression at the transcriptional level, although only in the temporal cortex. In the hippocampus and frontal cortex, PEDF gene expression remained unaltered. Protein expression remained unaltered in all structures. Exposure to $\mathrm{ClH}$ did not affect learning and memory on the MWM task. This selective increase in gene expression in the temporal cortex might be a protective mechanism against the neuronal injury caused by $\mathrm{ClH}$. The results of the present study suggest that the effects that long-term exposure to $\mathrm{lH}$ has on memory are reversible.

\section{References}

1. Tufik S, Santos-Silva R, Taddei JA, Bittencourt LR. Obstructive sleep apnea syndrome in the Sao Paulo Epidemiologic Sleep Study. Sleep Med. 2010;11(5):441-6. http://dx.doi.org/10.1016/j.sleep.2009.10.005

2. Peppard PE, Young T, Barnet JH, Palta M, Hagen EW, Hla KM. Increased prevalence of sleep-disordered breathing in adults. Am J Epidemiol. 2013;177(9):1006-14. http:// dx.doi.org/10.1093/aje/kws342

3. Dematteis M, Godin-Ribuot D, Arnaud C, Ribuot C, StankeLabesque F, Pépin JL, et al. Cardiovascular consequences of sleep-disordered breathing: contribution of animal models to understanding the human disease. ILAR J. 2009;50(3):262-81. http://dx.doi.org/10.1093/ilar.50.3.262

4. Dumitrascu R, Heitmann J, Seeger W, Weissmann N, Schulz R. Obstructive sleep apnea, oxidative stress and cardiovascular disease: lessons from animal studies. Oxid Med Cell Longev. 2013;2013:234631. http://dx.doi. org/ $10.1155 / 2013 / 234631$

5. lyer SR. Sleep and type 2 diabetes mellitus- clinical implications. J Assoc Physicians India. 2012;60:42-7.

6. Goldbart A, Row B., Kheirandish L, Schurr A, Gozal E, Guo S., et al. Intermittent hypoxic exposure during light phase induces changes in cAMP response element binding protein activity in the rat CA1 hippocampal region: water maze performance correlates. Neuroscience. 2003;122(3):58590. http://dx.doi.org/10.1016/j.neuroscience.2003.08.054

7. Carreras A, Kayali F, Zhang J, Hirotsu C, Wang Y, Gozal D. Metabolic effects of intermittent hypoxia in mice: steady versus high-frequency applied hypoxia daily during the rest period. Am J Physiol Regul Integr Comp Physiol. 20121;303(7):R700-9.

8. Perry JC, Bergamaschi CT, Campos RR, Andersen ML, Casarini DE, Tufik S. Differential sympathetic activation induced by intermittent hypoxia and sleep loss in rats: Action of angiotensin (1-7). Auton Neurosci. 2011;160(12):32-6 http://dx.doi.org/10.1016/j.autneu.2010.11.006

9. Gozal D, Daniel JM, Dohanich GP. Behavioral and anatomical correlates of chronic episodic hypoxia during sleep in the rat. J Neurosci. 2001;21(7):2442-50.

10. Polotsky VY, Rubin AE, Balbir A, Dean T, Smith PL, Schwartz AR, et al. Intermittent hypoxia causes REM sleep deficits and decreases EEG delta power in NREM sleep in the C57BL/6J mouse. Sleep Med. 2006;7(1):7-16. http://dx.doi.org/10.1016/j.sleep.2005.06.006

11. Sunderram J, Androulakis IP. Molecular mechanisms of chronic intermittent hypoxia and hypertension. Crit Rev Biomed Eng. 2012;40(4):265-78. http://dx.doi. org/10.1615/CritRevBiomedEng.v40.i4.30

12. Poon VY, Choi S, Park M. Growth factors in synaptic function. Front Synaptic Neurosci. 2013;5:6. http:// dx.doi.org/10.3389/fnsyn.2013.00006

13. Sanagi T, Yabe T, Yamada H. Adenoviral gene delivery of pigment epithelium-derived factor protects striatal neurons from quinolinic acid-induced excitotoxicity. J Neuropathol Exp Neurol. 2010;69(3):224-33. http:// dx.doi.org/10.1097/NEN.0b013e3181cfc46f

14. Taniwaki T, Hirashima N, Becerra SP, Chader GJ, Etcheberrigaray R, Schwartz JP. Pigment epitheliumderived factor protects cultured cerebellar granule cells against glutamate-induced neurotoxicity. J Neurochem. 1997;68(1):26-32. http://dx.doi. org/10.1046/j.1471-4159.1997.68010026.x

15. Yabe T, Sanagi T, Yamada H. The neuroprotective role of PEDF: implication for the therapy of neurological disorders. Curr Mol Med. 2010;10(3):259-66. http:// dx.doi.org/10.2174/156652410791065354

16. Sanagi T, Yabe T, Yamada H. Gene transfer of PEDF attenuates ischemic brain damage in the rat middle cerebral 
artery occlusion model. J Neurochem. 2008;106(4):184154. http://dx.doi.org/10.1111/j.1471-4159.2008.05529.x

17. Yabe T, Wilson D, Schwartz JP. NFkappaB activation is required for the neuroprotective effects of pigment epithelium-derived factor (PEDF) on cerebellar granule neurons. J Biol Chem. 2001;276(46):43313-9. http:// dx.doi.org/10.1074/jbc.M107831200

18. Smith ND, Schulze-Hoepfner FT, Veliceasa D, Filleur S, Shareef S, Huang L, et al. Pigment epithelium-derived factor and interleukin-6 control prostate neuroendocrine differentiation via feed-forward mechanism. J Urol. 2008;179(6):2427-34. http://dx.doi.org/10.1016/j. juro.2008.01.081

19. Yang XM, Yafai Y, Wiedemann P, Kuhrt H, Wang Y-S, Reichenbach A, et al. Hypoxia-induced upregulation of pigment epithelium-derived factor by retinal glial (Müller) cells. J Neurosci Res. 2012;90(1):257-66. http:// dx.doi.org/10.1002/jnr.22732

20. Fernández-Barral A, Orgaz JL, Gomez V, del Peso L, Calzada MJ, Jiménez B. Hypoxia negatively regulates antimetastatic PEDF in melanoma cells by a hypoxia inducible factor-independent, autophagy dependent mechanism. PLoS One. 2012;7(3):e32989. http://dx.doi. org/10.1371/journal.pone.0032989

21. Xie H, Yung W. Chronic intermittent hypoxia-induced deficits in synaptic plasticity and neurocognitive functions: a role for brain-derived neurotrophic factor. Acta Pharmacol Sin. 2012;33(1):5-10. http://dx.doi. org/10.1038/aps.2011.184

22. Julian GS, de Oliveira RW, Perry JC, Tufik S, Chagas JR. Validation of housekeeping genes in the brains of rats submitted to chronic intermittent hypoxia, a sleep apnea model. PLoS One. 2014;9(10):e109902. http:// dx.doi.org/10.1371/journal.pone.0109902

23. Row BW, Kheirandish L, Cheng Y, Rowell PP, Gozal D. Impaired spatial working memory and altered choline acetyltransferase (CHAT) immunoreactivity and nicotinic receptor binding in rats exposed to intermittent hypoxia during sleep. Behav Brain Res. 2007;177(2):308-14. http://dx.doi.org/10.1016/j.bbr.2006.11.028

24. Shan X, Chi L, Ke Y, Luo C, Qian S, Gozal D, et al. Manganese superoxide dismutase protects mouse cortical neurons from chronic intermittent hypoxia-mediated oxidative damage. Neurobiol Dis. 2007;28(2):206-15 http://dx.doi.org/10.1016/j.nbd.2007.07.013

25. Row BW, Kheirandish L, Neville JJ, Gozal D. Impaired spatial learning and hyperactivity in developing rats exposed to intermittent hypoxia. Pediatr Res. 2002;52(3):449-53. http://dx.doi.org/10.1203/00006450-200209000-00024

26. Wall AM, Corcoran AE, O'Halloran KD, O'Connor JJ. Effects of prolyl-hydroxylase inhibition and chronic intermittent hypoxia on synaptic transmission and plasticity in the rat CA1 and dentate gyrus. Neurobiol Dis. 2014;62:8-17. http://dx.doi.org/10.1016/j.nbd.2013.08.016

27. Shiota S, Takekawa H, Matsumoto SE, Takeda K, Nurwidya F, Yoshioka Y, et al. Chronic intermittent hypoxia/reoxygenation facilitate amyloid- $\beta$ generation in mice. J Alzheimers Dis. 2013;37(2):325-33.

28. Perry JC, D’Almeida V, Lima MM, Godoi FR, Vital MA, Oliveira MG, et al. Intermittent hypoxia and sleep restriction: motor, cognitive and neurochemical alterations in rats. Behav Brain Res. 2008;189(2):373-80. http:// dx.doi.org/10.1016/j.bbr.2008.01.014

29. Lavie L, Lavie P. Ischemic preconditioning as a possible explanation for the age decline relative mortality in sleep apnea. Med Hypotheses. 2006;66(6):1069-73. http:// dx.doi.org/10.1016/j.mehy.2005.10.033

30. Lange J, Yafai Y, Reichenbach A, Wiedemann P, Eichler W. Regulation of pigment epithelium-derived factor production and release by retinal glial (Müller) cells under hypoxia. Invest Ophthalmol Vis Sci. 2008;49(11):5161-7. http://dx.doi.org/10.1167/iovs.08-2201

31. Veasey SC, Davis CW, Fenik P, Zhan G, Hsu YJ, Pratico D, et al. Long-term intermittent hypoxia in mice: protracted hypersomnolence with oxidative injury to sleep-wake brain regions. Sleep. 2004;27(2):194-201.

32. Notari L, Miller A, Martínez A, Amaral J, Ju M, Robinson G, et al. Pigment epithelium-derived factor is a substrate for matrix metalloproteinase type 2 and type 9: implications for downregulation in hypoxia. Invest Ophthalmol Vis Sci. 2005;46(8):2736-47. http://dx.doi.org/10.1167/ iovs.04-1489

33. Kalaria RN, Spoors L, Laude EA, Emery CJ, Thwaites-Bee D, Fairlie J, et al. Hypoxia of sleep apnoea : cardiopulmonary and cerebral changes after intermittent hypoxia in rats. Respir Physiol Neurobiol. 2004;140(1):53-62. http:// dx.doi.org/10.1016/j.resp.2004.01.003

\section{About the authors}

\section{Guilherme Silva Julian}

Master's Student. Department of Psychobiology, Federal University of São Paulo Paulista School of Medicine, São Paulo, Brazil.

\section{Renato Watanabe de Oliveira}

Master's Student. Department of Psychobiology, Federal University of São Paulo Paulista School of Medicine, São Paulo, Brazil.

\section{Vanessa Manchim Favaro}

Doctoral Student. Department of Psychobiology, Federal University of São Paulo Paulista School of Medicine, São Paulo, Brazil.

\section{Maria Gabriela Menezes de Oliveira}

Associate Professor. Department of Psychobiology, Federal University of São Paulo Paulista School of Medicine, São Paulo, Brazil.

\section{Juliana Cini Perry}

Postdoctoral Researcher. Department of Psychobiology, Federal University of São Paulo Paulista School of Medicine, São Paulo, Brazil. 

expression, although not that of the protein itself, in the temporal cortex of rats

\section{Sergio Tufik}

Full Professor. Department of Psychobiology, Federal University of São Paulo Paulista School of Medicine, São Paulo, Brazil.

Jair Ribeiro Chagas

Associate Professor. Department of Psychobiology, Federal University of São Paulo Paulista School of Medicine, São Paulo; and Department of Biosciences, Federal University of São Paulo, Baixada Santista Campus, Santos, Brazil. 